\title{
Analisis Dampak Hutang Luar Negeri terhadap Pertumbuhan Ekonomi, Pengangguran dan Kemiskinan
}

\author{
Tulus Widjajanto1, Didi Zainuddin², \& Irwan Agus ${ }^{3}$ \\ 1,2,3 Universitas Indrapasta PGRI \\ 1,2,3 Mahasiswa Pascasarjana S3 Ekonomi, Universitas Borobudur
}

\begin{abstract}
ARTICLE INFO
Article History:

Received 9 November 2021

Revised 18 Desember 2021

Accepted 23 Desember 2021

Published 30 Desember 2021

ABSTRACT

This research aims to find out the impact of foreign debt on economic growth, unemployment and poverty in Indonesia, this research uses data available from BPS in the form of secondary data used as quantitative analysis on an annual basis from the period 1988 to 2019. Furthermore, the data is processed by regression method using SPSS version 24. Based on this research has the result of the simultaneous influence between foreign debt on economic growth, poverty

\section{Keywords:}

Foreign Debt;

Economic Growth;

Unemployment;

Poverty. and unemployment. With a significance value of 0.000 It means that there is a simultaneously significant influence between economic growth, poverty and unemployment on foreign debt. Where the amount of contribution made by economic growth, poverty and unemployment to foreign debt is indicated by the value of Adjusted $R$ Square of 0.508 or $50.8 \%$ of which $49.2 \%$ has a partial influence between foreign debt and economic growth. With the value of the significance of economic growth of 0.002 and the value of the Beta negative coefficient table (-14348.178), so it can be said that if there is an increase in foreign debt by 1 point, there will be a decrease in economic growth of 14348,178 points.
\end{abstract}

Penelitian ini untuk bertujuan untuk mengetahui dampak hutang luar negeri terhadap pertumbuhan ekonomi, pengangguran dan kemiskinan di Indonesia, riset ini menggunakan data yang tersedia dari BPS berupa data sekunder yang dipakai sebagai analisis kuantitatif secara tahunan mulai periode 1988 sampai dengan 2019. Selanjutnya data tersebut diolah dengan metode regresi menggunakan SPSS versi 24. Berdasarkan riset ini memiliki hasil adanya pengaruh secara simultan antara hutang luar negeri terhadap pertumbuhan ekonomi, kemiskinan dan pengangguran. Dengan nilai signifikansinya $0.000 \mathrm{Hal}$ ini maknanya terdapat pengaruh yang signifikan secara simultan (bersama) antara pertumbuhan ekonomi, kemiskinan dan pengangguran terhadap hutang luar negeri. Dimana besarnya kontribusi yang diberikan oleh pertumbuhan ekonomi, kemiskinan dan pengangguran terhadap hutang luar negeri ditunjukkan oleh nilai Adjusted R Square sebesar 0,508 atau 50.8\% dimana 49,2\% terdapat pengaruh secara partial antara hutang luar negeri dengan pertumbuhan ekonomi. Dengan nilai signifikansi pertumbuhan ekonomi sebesar 0.002 dan nilai tabel coefficient Beta negative (-14348.178), sehingga dapat dikatakan bahwa bila terjadi kenaikkan hutang luar negeri sebesar 1 point, maka Akan terjadi penurunan pertumbuhan ekonomi sebesar 14348,178 point.

\section{Corresponding Author:}

Tulus widjajanto

Email: tulus.nairtech@gmail.com

How to Cite: Widjajanto, T, Zainudin, D., Agus, I. (2021). Analisis dampak hutang luar negeri terhadap pertumbuhan ekonomi, pengangguran, dan kemiskinan. Sosio e-Kons, 13. (03),199-207 


\section{PENDAHULUAN}

Pembangunan infrastruktur di Indonesia secara besar-besaran yang dilakukan sangat mempengaruhi pertumbuhan ekonomi negara, seperti pembangunan infrastruktur jalan tol, bandara, dan pelabuhan yang ada. Hal ini akan sangat mempengaruhi keuangan negara apabila menggunakan dana yang bersumber dari hutang luar negeri. muncul pemberitaan mengenai kondisi utang luar negeri Indonesia yang dinilai sangat tinggi dan mengkhawatirkan. jika pemerintah tidak bisa mengatur jumlah hutang yang ada, akan berdampak kepada kesetabilan ekonomi masyarakat yang berdampak kepada rendahnya pertumbuhan ekonomi. Sebagian masyarakat mengatakan bahwa pembangunan yang dilakukan Jokowi hanya memperbanyak hutang negara Indonesia. Namun, pada kenyataannya utang negara Indonesia saat ini masih pada batas yang wajar. Akan tetapi Ekonom Bank Dunia di Indonesia Frederico Gil Sander berpendapat bahwa rasio hutang pemerintah Indonesia saat ini masih rendah dibandingkan dengan beberapa negara dengan ekonomi maju dan negara yang berpendapatan menengah. Sebagian besar masyarakat Indonesia masih menganggap bahwa hutang luar negeri Indonesia adalah utang yang timbul karena kegiatan pemerintahan saja.

Hutang luar negeri yang dimiliki Indonesia bukan milik pemerintahan saja, tetapi juga dari hutang milik bank sentral dan hutang milik swasta. Berdasarkan data dari $\mathrm{BI}$, hutang luar negeri pada Maret 2017 sebesar US $\$ 358,732$ miliar setara dengan Rp4.663,52 triliun. Dimana hutang luar legeri tersebut terdiri dari hutang pemerintah sebesar $50,49 \%$, hutang bank sentral sebesar $1 \%$, dan swasta memiliki hutang sebesar $48,51 \%$ dari total keseluruhan utang luar negeri Indonesia. Berdasarkan data diatas bahwa porsi utang luar negeri yang tinggi tidak semata-mata dari utang luar negeri pemerintah saja.

Todaro (2002) berpendapat bahwa tumbuhnya jumlah penduduk dan naiknya jumlah angkatan kerja (AK) secara tradisional dapat menjadi faktor yang baik untuk tumbuhnya ekonomi. Jumlah tenaga kerja yang tersedia lebih banyak akan meningkatkan jumlah produksi, sedangkan bertambahnya penduduk akan menjadi target pasar yang besar pula. Meski demikian hal tersebut masih menjadi pertanyaan apakah benar laju pertumbuhan penduduk yang cepat benar benar akan memberikan dampak positif atau negatif dari pembangunan ekonominya.

Permasalahan tenaga kerja seperti yang kita lihat akhir-akhir ini merupakan hal yang memprihatinkan dan merupakan faktor fundamental, hingga saat ini masalah tenaga kerja masih tertuju pada tingginya angka pengangguran. Seperti yang kita lihat fenomena mendasar yang terjadi dimana jumlah pengangguran memang sangat tinggi dan bisa menjadi indikator penghambat dari proses jalannya perekonomian suatu negara. Apabila tenaga kerja menjadi salah satu faktor yang mempengaruhi pertumbuhan ekonomi di Indonesia selain utang luar negeri dan tenaga kerja.

Ekspor dapat menentukan peningkatan PDB yaitu. Hal ini menggambarkan aktifitas belanja negara lain terhadap barang buatan perusahaan di dalam negeri. Dan salah satu indikator yang menentukan tingginya ekspor yaitu kemampuan dari Negara tersebut untuk bersaing dalam menciptakan dan mengeluarkan barang-barang yang dapat diserap oleh pasaran luar negeri. (Sadono Sukirno, 2008: 205). Ekspor barang dan jasa negara Indonesia kebanyakan masih bersifat memenuhi pesanan atau datang pembeli. Sifatnya bukan menyerang atau masuk ke negara lain. Dimana barang ekspor Indonesia belum bisa menjadi komoditas ekspor yang memiliki daya saing. Dan dapat menjadi kelemahan ekspor barang dan jasa yang dimiliki Indonesia. Pemerintah sendiri berupaya mendorong pengembangan ekspor untuk industi padat karya seperti industri makanan minuman dan tembakau, industri mainan anak, industri tekstil dan pakaian jadi serta industri furniture.

\section{METODE}

Riset ini menggunakan metode analisa kuantitatif untuk mengetahui adanya pengaruh hutang luar negeri terhadap pertumbuhan ekonomi, pengangguran dan kemiskinan. Selain itu dalam analisa 
kuantitatif akan dilihat arah dari pengaruh tersebut. Apakah variable-variabel independent atau variable $X$ (pertumbuhan ekonomi, pengangguran dan kemiskinan) searah atau berlawanan arah dengan variable dependent atau variable $Y$ (hutang luar negeri). Data yang digunakan adalah data hutang luar negeri, pertumbuhan ekonomi, kemiskinan, dan pengangguran secara tahunan mulai periode 1988 sampai dengan 2019.

Selanjutnya data tersebut diolah dengan metode regresi menggunakan SPSS versi 24 Sebagai dasar melakukan analisis kuantitatif, yaitu pada pengaruh hutang luar negeri terhadap pertumbuhan ekonomi, pengangguran dan kemiskinan. Ada tidaknya pengaruh tersebut ditunjukkan nilai signifikansi pada metoda regresi linier dengan menggunakan software SPSS versi 24. Bila terdapat hubungan baik secara simultan maupun parsial, nilai signifikansinya dibawah 0.005 , dan bila tidak terdapat hubungan nilai signifikansinya diatas 0.005 .

Bila tidak terdapat hubungan antara hutang luar negeri dengan pertumbuhan ekonomi, pengangguran dan kemiskinan, artinya ada pengaruh lain yang mempengaruhi variable-variabel tersebut. Dari pembahasan masalah diatas, dapat ditentukan Hipotesis untuk merumuskan permasalahan sebagai berikut:

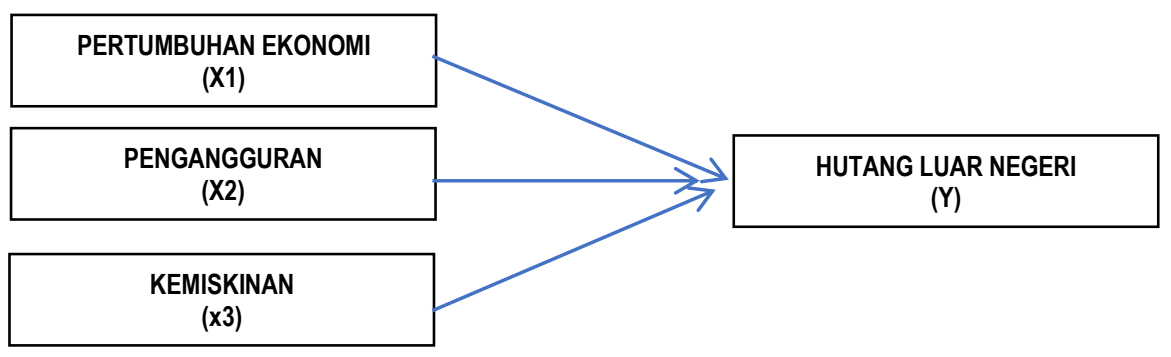

Sumber : Variabel Penelitian

Gambar 1. Krangka berfikir

Hipotesis dalam riset ini berupa jawaban sementara atas masalah yang telah dirumuskan. Dari penjelasan teori dan perumusan masalah diatas, maka Hipotesis dirumuskan sebagai berikut:

1. Adanya pengaruh secara simultan antara angka kemiskinan, pengangguran dan pertumbuhan ekonomi terhadap hutang luar negeri.

2. Terdapat pengaruh parsial antara hutang luar inegeri terhadap angka kemiskinan

3. Terdapat pengaruh parsial antara hutang luar negeri iterhadap pertumbuhan ekonomi

4. Tidak terdapat pengaruh parsial antara hutang luar negeri terhadap pengangguran

Dari perumusan masalah diatas, Hipotesis yang dapat dirumuskan sebagai berikut:

HO = Hutang Luar Negeri tidak berpengaruh terhadap Pertumbuhan Ekonomi, Angka Kemiskinan dan Tingkat Pengangguran.

H1 = Hutang Luar Negeri berpengaruh terhadap Pertumbuhan Ekonomi, Angka Kemiskinan dan Tingkat Pengangguran.

\section{HASIL DAN PEMBAHASAN}

\section{Hasil}

Pada dasarnya negara berkembang seperti Indonesia menjadikan pajak sebagai pendapatan utama penerimaan negara, seharusnya ada tumpuan pendapatan lain dari sektor ekspor, namun pada kenyataannya pemasukan anggaran kas negara belum dapat terpenuhi dari pajak yang didapat sehingga dibutuhkan sumber pendapatan lainnya dari berbagai sector keuangan untuk memenuhi 
anggaran belanja pemerintah. Maka dari itu ULN (utang luar negeri) menjadi salah satu alternative yang diambil pemerintah dan pihak swasta berupa suntikan dana asing untuk memenuhi anggran belanja bagi pemerintah dan tambahan modal bagi swasta, hal ini dikarnakan terbatasnya dana yang tersedia di dalam negeri menyebabkan pihak pemerintah dan swasta untuk mencari sumber pendanaan lain. ULN menjadi posisi kewajiban aktual penduduk Indonesia kepada bukan penduduk pada suatu waktu (Bank Indonesia, 2014). Maka dari itu ULN dapat dijadikan sebagai sumber pendapatan sementara. Menurut Yustika (2009) pemanfaatan ULN diperuntukkan sebagai upaya untuk mengatasi kesenjangan itabungan atau ïnvestasi dan ketimpangan neraca pembayaran dalam membantu negara berkembang melaksanakan pembangunan yang mandiri.

Kondisi perekonomian di negara berkembang yang belum stabil memaksa pemerintah untuk melakukan ULN sebagai salah satu sumber pendanaan. Melihat dari sisi neraca pembayaran, ULN dapat menutup kesenjangan ekspor dan impor sehingga mampu mengurangi penggunaan stok anggaran nasional (Boediono, 2000:84). Penurunan stok anggaran nasional memberikan gambaran defisit sehingga kebijakan pemerintah untuk melakukan ULN sebagai pengganti stok nasional dalam mengatasi kesenjangan impor dalam neraca pembayaran.

Pemanfaatan ULN (utang luar negeri) secara optimal dan terkontrol akan bisa memperbaiki kondisi perekonomian negara. Dengan anggaran yang didapat dari ULN diharapkan dapat meningkatkan jumlah investasi dalam perbaikan ekonomi. Dampak dari perbaikan ekomnomi akan memberikan kestabilan ekonomi yang baik secara bertahap pada negara tersebut sehingga kebutuhan akan modal asing sedikit berkurang. Berdasarkan Statistik Utang Luar Negeri Indonesia Vol. X, Juli 2019 yang dikeluarkan oleh Kementrian Keuangan Republik Indonesia dan Bank Indonesia, diperoleh data sebagai berikut:

Tabel 1.

Posisi Hutang Luar Negeri menurut Kelompok Peminjam

\begin{tabular}{clccccc}
\hline No & \multicolumn{1}{c}{ Posisi Hutang } & 2015 & 2016 & 2017 & 2018 & 2019 \\
\hline 1 & Pemerintah dan Bank Sentral/ Government and & 142.608 & 158.283 & 180.622 & 186.275 & 197.522 \\
& Central Bank & & & & & \\
& 1.1 Pemerintah / Government & 137.396 & 154.875 & 177.318 & 183.197 & 194.522 \\
& 1.2 Bank Sentral / Central Bank & 5.212 & 3.408 & 3.304 & 3.078 & 2.982 \\
Swasta / Private & 168.123 & 161.722 & 171.847 & 191.041 & 197.787 \\
& 2.1 Lembaga Keuangan / Financial Corporations & 42.997 & 40.062 & 40.563 & 45.251 & 46.17 \\
2.1.1 Bank / Bank & 31.92 & 30.247 & 30.3 & 34.715 & 35.757 \\
2.1.1 LKBB / Nonbank Financial Corporations & 11.077 & 9.815 & 10.263 & 10.537 & 11.413 \\
2.2 Bukan Lembaga Keuangan / Nonfinancial & 125.125 & 121.661 & 131.284 & 145.789 & 150.617 \\
& Corporations $\quad$ & & & & \\
$\quad$ Total (1 + 2) & 310.73 & 320.006 & 352.469 & 377.316 & 395.309 \\
\hline
\end{tabular}

Sumber : SULNI Vol XI September 2019

Berdasarkan informasi diatas kenaikan hutang luar negeri Indonesia dapat digambarkan kenaikannya dari 2016 sampai 2019 sebagai berikut:

Tabel 2.

Data Pertumbuhan Hutang per Periode

\begin{tabular}{lccc}
\hline \multicolumn{1}{c}{ Posisi Hutang } & Growth Period & \\
& $2016-2017$ & $2017-2018$ & $2018-2019$ \\
\hline Pemerintah dan Bank Sentral/ Government and Central Bank & $114 \%$ & $103 \%$ & $106 \%$ \\
1.1 Pemerintah / Government & $114 \%$ & $103 \%$ & $106 \%$ \\
1.2 Bank Sentral / Central Bank & $97 \%$ & $93 \%$ & $97 \%$ \\
Swasta / Private & $106 \%$ & $111 \%$ & $104 \%$ \\
2.1 Lembaga Keuangan / Financial Corporations & $101 \%$ & $112 \%$ & $102 \%$ \\
2.1.1 Bank / Bank & $100 \%$ & $115 \%$ & $103 \%$ \\
2.1.1 LKBB / Nonbank Financial Corporations & $105 \%$ & $103 \%$ & $108 \%$ \\
2.2 Bukan Lembaga Keuangan / Nonfinancial Corporations & $108 \%$ & $111 \%$ & $103 \%$ \\
\hline Sumber: SULN/ Vol XI September 2019 & &
\end{tabular}

Sumber : SULNI Vol XI September 2019 
Dari data diatas dapat diketahui komposisi hutang pemerintah sampai dengan bulan Juli 2019, Hutang Pemerintah dan Bank Central naik sebesar 6\% bila dibandingkan dengan Hutang tahun 2018. Kenaikkan tersebut diakibatkan naiknya hutang Pemerintah sebesar $6 \%$, namun terjadi penurunan sebesar 3\% pada hutang Bank Central. Kenaikkan hutang yang lain diakibatkan oleh naiknya hutang dari sector Swasta yaitu sebesar 4\% bila dibandingkan dengan tahun 2018. Kenaikan ini disebabkan naiknya hutang pada LKBB yaitu sebesar $8 \%$ dibandingkan dengan tahun 2018. hutang pemerintah diluar negeri yang direstrukturisasi ulang melalui Paris Club dan Moratorium. Akan menghasilkan restrukturisasi berupa penggabungan beberapa loan dari berbagai sektor ekonomi. berikut data hutang luar negeri, pertumbuhan ekonomi, pengangguran dan kemiskinan yang diambil dari data BPS, BI, Kementrian Keuangan dan Bank Dunia dari tahun 1988 sampai dengan September 2019, sebagai berikut:

Tabel 2.

Data hutang luar negeri, pertumbuhan ekonomi, pengangguran dan kemiskinan

\begin{tabular}{|c|c|c|c|c|c|}
\hline $\mathrm{n}$ ke & THN & HLN & PERT & PENG & MISK \\
\hline 1 & 1988 & 54.054 & 5.7 & 2.9 & 42.3 \\
\hline 2 & 1989 & 59.380 & 7.5 & 2.8 & 40.6 \\
\hline 3 & 1990 & 69.848 & 7.4 & 2.5 & 35.0 \\
\hline 4 & 1993 & 89.147 & 6.5 & 2.6 & 30.0 \\
\hline 5 & 1994 & 107.809 & 7.5 & 4.4 & 27.2 \\
\hline 6 & 1995 & 124.389 & 8.1 & 0.0 & 25.9 \\
\hline 7 & 1996 & 128.990 & 7.8 & 4.9 & 22.5 \\
\hline 8 & 1997 & 136.322 & 4.7 & 4.7 & 34.0 \\
\hline 9 & 1998 & 151.467 & -13.1 & 5.5 & 49.5 \\
\hline 10 & 1999 & 151.788 & 0.8 & 6.4 & 48.0 \\
\hline 11 & 2000 & 116.400 & 4.9 & 6.1 & 38.7 \\
\hline 12 & 2001 & 126.300 & 3.4 & 8.1 & 37.9 \\
\hline 13 & 2002 & 124.900 & 3.7 & 9.1 & 38.4 \\
\hline 14 & 2003 & 124.000 & 4.1 & 9.7 & 37.3 \\
\hline 15 & 2004 & 127.500 & 5.1 & 9.9 & 36.2 \\
\hline 16 & 2005 & 134.504 & 5.6 & 11.2 & 35.1 \\
\hline 17 & 2006 & 132.633 & 5.5 & 10.3 & 39.3 \\
\hline 18 & 2007 & 141.180 & 6.3 & 9.1 & 37.2 \\
\hline 19 & 2008 & 155.080 & 6.1 & 8.4 & 35.0 \\
\hline 20 & 2009 & 172.871 & 4.6 & 7.9 & 32.5 \\
\hline 21 & 2010 & 202.413 & 6.1 & 7.1 & 31.0 \\
\hline 22 & 2011 & 225.375 & 6.2 & 7.5 & 29.9 \\
\hline 23 & 2012 & 252.364 & 6.0 & 6.1 & 28.6 \\
\hline 24 & 2013 & 266.109 & 5.6 & 6.2 & 28.6 \\
\hline 25 & 2014 & 293.328 & 5.0 & 5.9 & 27.7 \\
\hline 26 & 2015 & 293.328 & 4.9 & 6.2 & 28.5 \\
\hline 27 & 2016 & 320.006 & 5.0 & 5.6 & 27.8 \\
\hline 28 & 2017 & 353.156 & 5.1 & 5.5 & 26.6 \\
\hline 29 & 2018 & 377.316 & 5.2 & 5.3 & 25.67 \\
\hline 30 & 2019 & 395.309 & 5.3 & 5.0 & 25.14 \\
\hline
\end{tabular}

Sumber: Data BPS, BI, Kementrian Keuangan Dan Bank Dunia Diolah

\section{Pembahasan}

Dari hasil pengolahan data menggunakan SPSS versi 24 tersebut diatas, didapatkan hasil uji hipotesis sebagai berikut: 
Tabel 4.

Uji Multikolinearitas

Coefficient a

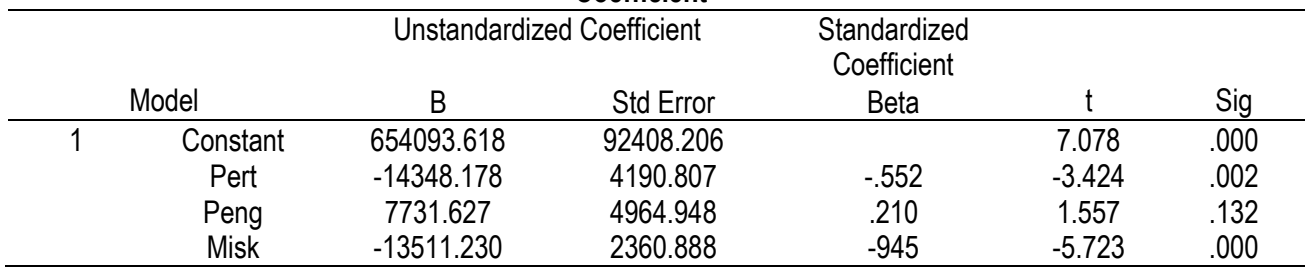

Dependent Variable : HUTLN

Berdasarkan olah data diatas terdapat pengaruh secara partial antara hutang luar negeri dengan pertumbuhan ekonomi. Hal tersebut terlihat pada tabel 4 dimana nilai signifikansi pertumbuhan ekonomi sebesar 0.002 yang mana nilai tersebut dibawah 0.005 . Tetapi dari tabel coefficient tersebut dijumpai nilai Beta negative (-14348.178), sehingga dapat dikatakan bahwa bila terjadi kenaikkan hutang luar negeri sebesar 1 point, maka Akan terjadi penurunan pertumbuhan ekonomi sebesar 14348,178 point.

Tidak terdapat pengaruh secara partial antara hutang luar negeri dengan pengangguran. Pada tabel 11 nilai signifikansinya sebesar 0.132 dimana nilai tersebut lebih besar dari 0.005 . Hal ini bisa disimpulkan bahwa tingkat pengangguran dapat disebabkan oleh factor lain selain hutang luar negeri. Dan terdapat pengaruh secara partial antara hutang luar negeri dengan kemiskinan. Terlihat dalam tabel 11 nilai siginfikansinya 0.000 dibawah 0.005 . Dengan melihat nilai coefficient beta yang negative, artinya arah dari factor kemiskinan adalah berbanding terbalik dengan hutang luar negeri. Sehingga dapat dikatakan bahwa bila ada kenaikkan hutang luar negeri sebesar 1 point, maka akan terjadi penurunan angka kemiskinan sebesar 13511,230 point.

Tabel 5.

Uji Autokolerasi,

Model Summary

\begin{tabular}{ccccc}
\hline Model & $\mathrm{R}$ & $\mathrm{R}$ Square & $\begin{array}{c}\text { Adjusted R } \\
\text { Square }\end{array}$ & $\begin{array}{c}\text { Std. Error Of } \\
\text { The Estimate }\end{array}$ \\
\hline 1 & $.747^{\mathrm{a}}$ & .559 & .508 & 67405.30189 \\
\hline Predictor (constant)
\end{tabular}

Predictor: (constant) MISK, PENG, PERT

Dimana terdapat pengaruh secara simultan antara hutang luar negeri dengan pertumbuhan ekonomi, kemiskinan dan pengangguran. Hal tersebut terlihat pada tabel 5 nilai signifikansinya 0.000 dimana nilai tersebut dibawah 0.05 . Hal ini bisa diartikan bahwa terdapat pengaruh yang signifikan secara simultan (bersama) antara pertumbuhan ekonomi, kemiskinan dan pengangguran terhadap hutang luar negeri. Dimana besarnya kontribusi yang diberikan oleh pertumbuhan ekonomi, kemiskinan dan pengangguran terhadap hutang luar negeri ditunjukkan oleh nilai Adjusted $R$ Square sebesar 0,508 atau 50.8\% dimana 49,2\% kontribusi terhadap hutang luar negeri dipengaruhi oleh faktor lain.

Menurut Umar Juoro (1994), pada tahun 1950 dan 1960-an, dalam semangat duet ekonomi Harrod-Domar, bantuan luar negeri memilik dampak positif terhadap tumbuhnya ekonomi dan naiknya jumlah tabungan masyarakat sebagai dampak lanjutannya. Karena dengan adanya bantuan dana dari luar negeri dapat meningkatkan investasi yang selanjutnya meningkatkan pendapatan dan tabungan domestik dan seterusnya. artinya secara teori, bantuan luar negeri justru menghasilkan dampak pengganda (multiplier effects) yang positif terhadap pertumbuhan ekonomi.

Pada tahun 1970-an, dua ekonom lain Keith Griffin dan John Enos dalam bukunya Foreign Assistance: Objectives and Consequences" menyatakan bahwa hutang yang berasal dari luar negeri memiliki dampak negatif terhadap tumbuhnya ekonomi. Hal ini sesuai riset empiris yang menyatakan utang luar negeri berkorelasi negatif pada pertumbuhan ekonomi dan peningkatan jumlah tabungan masyarakat. Bantuan luar negeri telah membuat pemerintah meningkatkan pengeluaran yang 
mengurangi dorongan untuk meningkatkan penerimaan pajak dan sebagainya. Ekonom di era berikutnya juga melakukan studi yang mendukung kesimpulan tersebut.

Todaro (2000) berpendapat bahwa akumulasi dari jumlaj hutang luar negeri (external debt) merupakan suatu hal yang lumrah terjadi. Rendahnya tabungan dalam negeri tidak memungkinkan untuk memenuhi kebutuhan investasi, sehingga pemerintah negara berkembang harus mencari dana pinjaman dan penanaman modal dari luar negeri. Maka dari itu bantuan luar negeri bisa memberikan dampak yang sangat penting bagi negara yang bersangkutan untuk mengurangi kendala utamanya yang berupa kekurangan devisa, serta untuk menaikan pertumbuhan ekonominya.

Dari uji yang telah dilakukan, bahwa teori yang dikemukakan oleh Harold-Domar (1960) dan teori Todaro yang mengemukakan bahwa hutang luar negeri berpengaruh terhadap perrumbuhan ekonomi terbukti. Hal ini dapat dilihat dari signifikansi yang menunjukkan nilai 0.002 . Dilain hal teori yang dikemukakan oleh Keith Griffin dan John Enos (1970) yang mengatakan bahwa pinjaman luar negeri berdampak negative pada perrtumbuhan ekonomi. Dari hasil uji statistic terlihat bahwa hubungan antara hutang luar negeri dengan pertumbuhan ekonomi mempunyai arah negative artinya hubungan antara hutang luar negeri dan pertumbuhan ekonomi berbanding terbalik

Pada dasarnya jumlah kemiskinan tidak dapat dihilangkan, tetapi dapat dikurangi melalui program pembangunan ekonomi berkelanjutan, penekanan jumlah penduduk miskin telah menjadi tujuan pembangunan yang sangat fundamental sehingga menjadi toal ukur untuk menilai efektivitas keberhasilan program pembangunan. Karena pertumbuhan ekonomi dapat menjadi instrumen penting dalam menurunkan kemiskinan dan menaikan pendapatannya (income poverty).

Pemerintah Indonesia sadar terhadap pembangunan nasional yang menjadi salah satu upaya untuk tujuan masyarakat adil dan makmur. Oleh karnanya, berbagai kegiatan pembangunan telah diarahkan kepada pembangunan daerah khususnya daerah yang tingkat kemiskinan terus naik setiap tahunnya. Pembangunan daerah dilakukan secara terpadu dan berkelanjutan sesuai prioritas dan kebutuhan masing daerah dengan tujuan dan sasaran pembangunan nasional yang telah ditetapkan melalui pembangunan jangka pendek dan jangka panjang. Maka karena itu, salah satu indikator utama suksesnya pembangunan nasional adalah penurunan laju jumlah penduduk miskin. Efektivitas dalam menurunkan jumlah penduduk miskin merupakan pertumbuhan utama dalam memilih strategi atau instrumen pembangunan. Hal ini berarti salah satu kriteria utama pemilihan sektor titik berat atau sektor andalan pembangunan nasional adalah efektivitas dalam penurunan jumlah penduduk miskin (Pantjar Simatupang dan Saktyanu K, 2003).

Selain itu kemiskinan juga dapat terjadi karena hubungan sebab akibat (kausalitas melingkar) artinya tingkat kemiskinan yang tinggi terjadi karena rendahnya pendapatan perkapita, pendapatan perkapita yang rendah terjadi karena investasi perkapita yang rendah juga. Tingkat investasi perkapita yang rendah disebabkan oleh permintaan domestik perkapita yang rendah juga dan hal ini terjadi karena tingkat kemiskinan yang tinggi dan begitu seterusnya, sehingga membentuk sebuah lingkaran kemiskinan sebagai sebuah hubungan sebab dan akibat (teori Nurkse, 1952) dan telah dibuktikan untuk contoh kasus lingkar kemiskinan di Indonesia (Sumanta, Jurnal Kebijakan Ekonomi; 2005).

Dari hasil uji statistic dengan menggunakan metode regresi linier diketahui bahwa nilai signifikansinya 0.000 artinya terdapat hubungan secara parsial antara hutang luar negeri dengan kemiskinan mengingat nilai signifikansinya dibawah 0.005 . Namun arah dari hubungan tersebut adalah negative, yang berarti hubungan antara hutang luar negeri dan kemiskinan adalah berbanding terbalik. Hal tersebut menggambarkan bahwa bila terdapat kenaikkan 1 point pada komponen hutang luar negeri akan menyebabkan penurunan sebesar 13511.230 point.

Dengan adanya hal tersebut diatas, maka pemerintah harus mengoptimalkan penggunaan hutang luar negeri tersebut dan melakukan control pada penggunaannya, mengingat berdasarkan teori dan uji statistic pengaruh hutang luar negeri dapat menurunkan tingkat kemiskinan masyarakat.

Pada uji statistic diatas tidak terlihat adanya hubungan secara parsial antara hutang luar negeri dengan pengangguran. Hal ini dapat ditunjukkan dengan adanya nilai signifikansi partial antara hutang luar negeri dengan pengangguran sebesar 0.132 yang mana nilai tersebut diatas 0.005 . Artinya ada 
factor lain yang dapat mempengaruhi pengangguran. Maka dari itu harus ada penelitian lanjutan untuk mengetahui apa yang mempengaruhi pengangguran.

\section{SIMPULAN DAN SARAN}

Berdasarkan hasil riset diatas dapat disimpulkan bahwa adanya pengaruh secara simultan antara variabel pertumbuhan ekonomi, pengangguran dan kemiskinan terhadap variabel hutang luar negeri, maka pemerintah harus terus berbenah diri guna mengalokasikan hutang luar negeri tersebut. Secara partial terdapat pengaruh secara signifikan antara pertumbuhan ekonomi dan kemiskinan terhadap hutang luar negeri, tetapi tidak terdapat pengaruh secara signifikan antara pengangguran dengan hutang luar negeri. Dan pemerintah harus menyampaikan dalam kebijakan yang mendukung baik dari segi kebijakan moneter dan kebijakan fiskal yang diambil oleh pemerintah agar mampu menggunakan dana dari hutang luar negeri untuk menaikan pertumbuhan ekonomi dan penurunan angka orang miskin di Indonesia. Maka dari itu hutang luar negeri yang didapatkan pemerintah seharusnya dapat dioptimalkan dalam pengelolaanya kepada sector produktif agar dapat memberikan efek yang positif terhadap pertumbuhan ekonomi serta menyerap lapangan pekerjaan.

\section{REFERENCES/DAFTAR PUSTAKA}

Agustina \& Reny. 2014. Pengaruh Ekspor, Impor, Nilai Tukar Rupiah, dan Tingkat Inflasi terhadap Cadangan Devisa Indonesia. Jurnal Wira Ekonomi Mikroskil, 4(2), 61-70.

Arikunto \& Suharsimi. 2010. Prosedur Penelitian Suatu Pendekatan Praktik. Cetakan Keempat Belas. Jakarta: Rineka Cipta.

Astanti \& Ayu. 2015. "Analisis Kausalitas Antara Utang Luar Negeri dan Pertumbuhan Ekonomi di Indonesia.Universitas Jember.

Atmadja \& Adwin S, (2000). Utang Luar Negeri Pemerintah Indonesia: Perkembangan dan Dampaknya. Jurnal Akuntansi \& Keuangan, 2(1), 83-94.

Atmadja \& Adwin S. (2000). Utang Luar Negeri Pemerintah Indonesia : Perkembangan dan Dampaknya, Jakarta : UKP

Ayadi, Folorunso S. and Ayadi, Felix O. (2008). The Impact of External Debt on Economic Growth: A Comparative Study of Nigeria and South Africa. Journal of Sustainable Development in Africa, 10(3), 234-264

Bank Indonesia. 2012. "Laporan Perekonomian Indonesia", diakses tanggal 5 Okt dari http://www.bi.go.id/id/publikasi/laporantahunan/perekonomian/Pages/LPI_2012.aspx

Boediono, (2000), Ekonomi Internasional, BFFE, Yogyakarta

Daniel Eka. (2016). Pengaruh Utang Luar Negeri, Tenaga Kerja, Dan Ekspor, Terhadap Produk Domestik Bruto Di Indonesia Tahun1986 - 2001. Universitas Negeri Yogyakarta.

George, Susan, (1992). The Debt Boomerang, New Jersey: Westview Press.

Griffin,Keith.dan Enos, John : Foreign Assistance: Objectives and Consequences. (1970)

Jhingan, M.L. (2004). Ekonomi Pembangunan dan Perencanaan. PT Raja Grafindo Persada. Jakarta.

Jhingan, M.L., (1983). The Economic of Development and Planning,16th Edition, New Delhi: Vicas Publishing House, Ltd.

Juoro,Umar : jurnal Pertumbuhan Ekonomi, Investasi dan Pinjaman Luar Negeri. Depok Bappenas, Cides (Center for Information and Development Studies) (1994)

Kusumosuwidho, sisdjatmo.1981."Angkatan Kerja”,dalam FEUI.1981. Dasar- Dasar Demografi. Jakarta LDFE-UI

Laporan Tahunan Bank Indonesia 1998/1999, Bank Indonesia, 2000.

Nopirin. (2000). Ekonomi Internasional, Edisi Ketiga. Yogyakarta: BPFE 
Nurske, R. (1952). Problems of Capital Formation in Underdeveloped Countries, Oxford: Basil Backwell. Payaman, J Simanjuntak. (1998). Pengantar Ekonomi Sumber Daya Manusia. Jakarta: Penerbit FE UI. Rostow, W.W., (1985). Pioneers in Development, Washington, D.C.: The World Bank.

Sadono Sukirno. 2008. Mikroekonomi: Teori Pengantar. Edisi Ketiga. Jakarta: PT Raja Grafindo Persada

Salvatore, Dominick, (1996), International Economics, 5th Edition, New Jersey: Prentice-Hall, Inc.

Simatupang, P \& Saktyanu K. D. 2003. Produksi Domestik Bruto, Harga, dan Kemiskinan, dalam Media Ekonomi dan Keuangan Indonesia.

Sumanta, J. 2005. Fenomena lingkaran kemiskinan di Indonesia: Analisis ekonometri regional data panel propinsi tahun 1999-2002. MPKP UI.

Tambunan, Tulus T.H., (1996). Perekonomian Indonesia, Jakarta: Ghalia Indonesia.

Todaro, M.P. 2000. Pembangunan Ekonomi di Dunia Ketiga (H.Munandar, Trans. Edisi Ketujuh ed.). Jakarta: Erlangga

Todaro. M. P (2002). Pembangunan Ekonomi di Dunia Ketiga. Jakarta:Penerbit Erlangga.

Yustika, A.E (2009). Ekonomi politik: kajian teoretis dan analisis empiris. Jogjakarta: Pustaka Belajar 